\title{
A content analysis of Turkish national high school health education curriculum using the health education curriculum analysis tool $(\text { HECAT })^{*}$
}

Volkan Serin1, I.D. Bilkent University, Turkey, vserin.tr@gmail.com, ORCID: 0000-0003-1235-786X
Armağan Ateşkan, I.D. Bilkent University, Turkey, ateskan@bilkent.edu.tr, ORCID: 0000-0001-5648-2385

\begin{abstract}
Health education helps students to promote their mental, social and physical well-being. Health educators follow a specific curriculum for health promotion in the high schools of Turkey. This study compared Turkish national high school health education curriculum (HEC) which is delivered at grade 9 with the health education curriculum analysis tool (HECAT) used in the United States. Recommendations for possible new K-12 health education curriculum and for existing and further grade 9 curricula to improve was also given. Content analysis was used as a research method. In this research, an appraisal strength table was created which was adapted from HECAT in order to compare the curricula. Only 45 objectives in the national curriculum were found compatible with 1802 expectations of HECAT (correspondence rates: $6 \%$ for all grades and $7 \%$ for grades $9-12$ ). Furthermore, the most represented level according to Bloom's revised taxonomy cognitive domains was understanding, whereas applying was minimum represented level in HEC. The findings also indicate that health education delivery grades and contents should be expanded immediately in Turkey same as in the U.S. due to several reasons emerged recent years on health. Moreover, this research suggests to form Turkish national health education standards (TNHES) for K-12 education and draft TNHES were shared in this study.
\end{abstract}

Keywords:, Health education, Curriculum evaluation, Content analysis

Received: 07.04.2020 Accepted: 03.08.2020 Published: 15.01 .2021

\section{INTRODUCTION}

According to the World Health Organization (WHO) the definition of health is "A state of complete physical, mental and social well-being and not merely the absence of disease or infirmity" (1948, p.100). Saracci (1997) claims this definition is too traditional and has problems, so he redefined health from a universal equality viewpoint as, "Health is a condition of well-being free of disease or infirmity and a basic and universal human right" (p. 1410). Since WHO defined the health after the Second World War, Saracci focused on equality all over the world after 49 years later. He also emphasized that the importance of health definition was not enough to be well understood. Therefore, education can help to understand the evolving needs of human health. Kann, Telljohann and Wooley (2007) stated that health education qualifies students with the latent competency to promote them to sustain and develop their wellness and increase control over and avoid health-risky behaviors. WHO (2012) described health educators as recognized staff who are hard-working, willing and dedicated. WHO (1986) and Eriksson and Lindstrom (2008) revealed another significant concept 'health promotion', which is called salutogenic theory and originated from the idea of allowing people to promote and improve their healthy life standards rather than on disease causing factors. Thus, the health can be promoted with the help of health education. More recently, the WHO (2016) also mentioned that health education plays an important role in the promotion of healthy activities in the Eastern Mediterranean region, including Turkey.

The Ministry of National Education (MoNE) regulates education in Turkey and prepares curricula for grades $\mathrm{K}$ through 12 . The implementation of health education was started in the middle 80s in Turkey (Sağlam, 1996). The accessible first regulation on health education course

\footnotetext{
*This study is derived from the first author's master's thesis entitled "A content analysis of Turkish national high school health education curriculum using the health education curriculum analysis tool (HECAT)" under the supervision of the second author and presented orally at EERA Conference ECER 2019.

${ }^{1}$ Corresponding author
} 
took part in military high school and non-commissioned officer high school in 1978. Afterwards, health education course was added for maritime vocational high school in 1980. Finally, health education course appeared in all secondary schools from 1983 onwards (MoNE, n.d.). Sağlam (1996) focused on the quality of health education and students' interest in it. Since the course was put into practice in 1984-1985 academic year in secondary schools in Turkey and the content of the program was prepared by the Ministry of Education, due to the problems encountered during the applications, he suggested the courses were not given effectively. At the end of the study, possible learning activities such as discussions, problem/case-solution, (statistical) tables and experimental support were put forward in order to solve the determined learning problems. On the other hand, Sağlam argued that teachers, who were involved in the study, shared their knowledge on topics. Teachers were thinking that courses were not adequate. The concepts were not efficiently taught and health education and biology have common topics which are repeated excessively and the practical part was not enough. Cerrah and Ayas (2003) conducted a study with biology teachers who give biology and health education courses. The study figured out that teachers were not pleased to give those two courses at the same time because of the discontinuity of them, which does not support significant learning. The other comment from teachers was related to students' knowledge level on health. The point was, students should come to secondary education from primary education with this awareness. Furthermore, health education is integrated into several subjects with courses on health-related topics in Turkish curricula. For early years (Kindergarten), health education is covered in pre-school education courses; in grades 1 to 3 , it is covered in life science; in grades 4 to 8 , it is covered in science; in grade 9 , there is a specific health education course, which is the topic of this study; and in grades 9 to 12 , it is covered in various units of biology course. There are also physical education courses in grades 1 through 12 that cover some aspects of health education. Above all, Health Education Curriculum (HEC) is implemented only in grade 9 and should cover all grades on an ongoing basis.

Some researchers examined the relationship between healthy behaviors and education in Turkey. Mocan and Altindag (2014) highlighted the importance of schooling and stated that education is a good indicator for being healthy. Similarly, Tansel and Karaoglan (2014) found that education has the strongest effect on all healthy behaviors. In addition, education even has a positive impact on healthy food choices. Both researchers claimed as a conclusion that the welleducated people can distinguish healthy or unhealthy effects of choices except alcohol. Unless otherwise stated, these studies do not explain the effect of the curriculum in particular. Moreover, no research has yet been conducted that reviews the quality of the health education curriculum (HEC) in Turkey. Therefore, there might be a gap for effective health education in Turkey according to statistical evidence (TURKSTAT, 2014 and 2017). Since grade 9 students are about 15 years old, there is a scope and sequence problem through $\mathrm{K}-12$ grades in terms of health education delivery. Existing HEC is delivered only in grade 9 under the name of "health education" for a year, one hour a week, in total 36 hours in not enough to improve healthy behaviors owing to older age and limited time (MoNE, 2012).

In the United States, the National Health Education Standards (NHES) were developed to maintain the promotion of health behaviors for students from all grades. The NHES provide a framework for health educators and other shareholders to create, adapt or select curricula, prepare instructional materials, and assess learners' achievement and progress. The main aim of the standards is to promote personal, family and community health. The first NHES were published in 1995. First seven of NHES were designed to standardize health education across the U.S. in the early 1990's. More than 20 years, the NHES became an approved reference in health education, providing a framework for the adoption of standards for most parts of States (CDC, 2015). In standard one, all knowledge expectations were typed and numbered in the pages specific to grades K-12 unless the aim was focusing on objective 9-12. For standards two through eight, a list of skills is given that broaden the concepts presented in each standard. All the NHES are listed in Table 1. 
Table 1. The NHES

\begin{tabular}{|c|c|c|}
\hline Standard & Content & Key Concept \\
\hline 1 & $\begin{array}{l}\text { Students will comprehend concepts related to health promotion and } \\
\text { disease prevention to enhance health. }\end{array}$ & $\begin{array}{l}\text { Knowledge } \\
\text { expectations }\end{array}$ \\
\hline 2 & $\begin{array}{l}\text { Students will analyze the influence of family, peers, culture, media, } \\
\text { technology, and other factors on health behaviors. }\end{array}$ & $\begin{array}{l}\text { Analyzing } \\
\text { internal and } \\
\text { external } \\
\text { influences }\end{array}$ \\
\hline 3 & $\begin{array}{l}\text { Students will demonstrate the ability to access valid information and } \\
\text { products and services to enhance health. }\end{array}$ & $\begin{array}{l}\text { Accessing } \\
\text { information }\end{array}$ \\
\hline 4 & $\begin{array}{l}\text { Students will demonstrate the ability to use interpersonal communication } \\
\text { skills to enhance health and avoid or reduce health risks. }\end{array}$ & $\begin{array}{l}\text { Interpersonal } \\
\text { communication }\end{array}$ \\
\hline 5 & $\begin{array}{l}\text { Students will demonstrate the ability to use decision-making skills to } \\
\text { enhance health. }\end{array}$ & $\begin{array}{l}\text { Decision- } \\
\text { making }\end{array}$ \\
\hline 6 & $\begin{array}{l}\text { Students will demonstrate the ability to use goal-setting skills to enhance } \\
\text { health. }\end{array}$ & Goal setting \\
\hline 7 & $\begin{array}{l}\text { Students will demonstrate the ability to practice health-enhancing } \\
\text { behaviors and avoid or reduce health risks. }\end{array}$ & $\begin{array}{l}\text { Self- } \\
\text { management }\end{array}$ \\
\hline 8 & $\begin{array}{l}\text { Students will demonstrate the ability to advocate for personal, family, and } \\
\text { community health. }\end{array}$ & Advocacy \\
\hline
\end{tabular}

Health education in the United States of America is regulated with the help of the Health Education Curriculum Analysis Tool (HECAT). This tool has been developed by Centers for Disease Control and Prevention ([CDC], 2012). This tool is used by health educators as a framework for the comprehensive and reliable assessment of health education curricula based on the NHES and the CDC's Characteristics of Effective Health Education Curricula in the U.S. HECAT has been standardized so that curricula can be adapted to the school needs to help students set goals and provide healthy behavioral outcomes (CDC, 2012). Some researchers have used HECAT in several studies as a tool to assess health education curricula (Falkenburry, 2011; Menzawa, 2014; Minbuta, Anzai, Naka, Yasuda, \& Menzawa, 2012). Falkenburry (2011) applied HECAT to assess an existing high school HEC to determine if it met the HECAT criteria. The study found that the curriculum at the selected site met most of the criteria of the HECAT. In addition to this, Falkenburry found that the curriculum lacks an assessment of students' self-skill progress such as individual check lists. Moreover, the curriculum did not provide rubrics for a teacher to assess students' works. The researcher deduced that HECAT was very subjective. There are eight NHES and the first one is determined as more specific and easier to assess than others which are more subjective. Another study that used HECAT was conducted by Minbuta, Anzai, Naka, Yasuda, and Menzawa (2012), and they aimed to examine a potential HEC and teaching aids for first two grades (1 and 2) in two elementary schools in Japan. There is no course called health education in the Japanese curriculum in the first two grades. Students encounter health content in their physical education class when they start grade 3. More studies are suggested as a need to examine sufficient hours and organization of contents. In the study, researchers achieved the expected results by using HECAT, Health Smart and Michigan Model tools. Menzawa (2014) emphasized that no comparison studies were conducted between Japanese and American elementary school health education courses. The purpose of the study was to examine health education in the U.S. and compared it with Japanese health education in the lower grades. Menzawa compared and analyzed the U.S. NHES and nine modules of HECAT) with the Japanese HEC. The analysis is based on the NHES Standard one "Students will comprehend concepts related to health promotion and disease prevention to enhance health" (CDC, 2015, p.1).

The purpose of this study was to compare the HEC in Turkey with HECAT. The main aim of this research is to identify necessary improvements to the curriculum which will facilitate a formation of Turkish national health education standards (TNHES) for K-12 education. That would better encourage students to adopt health-enhancing behaviors and skills, also help them to reduce health-risky behaviors. Therefore, HEC and HECAT were subjected to this study to 
compare similarities and differences between these two national educational tools on health and to compare two countries how they approach to health education.

The following research questions were explored in this study:

1. How does the current Turkish national high school health education curriculum (HEC) meet the Health Education Curriculum Analysis Tool (HECAT) criteria?

a. What are the results of comparison of HEC with HECAT?

b. What are the strengths and limitations of the current HEC according to the HECAT criteria?

\section{METHODS}

\section{Research design}

This research was designed as content analysis which is an effective way to criticize any two or more distinctive contexts -sometimes or mostly overlaps- according to Weber (1985), Krippendorff (1986) and Neuendorf (2002) to make valid implications from content. This qualitative content analysis study uses a newly created appraisal strength criteria that is adapted from HECAT as an instrument to compare HECAT with Turkish national high school health education curriculum.

\section{Data collection and Analysis}

The first step in the data collection process was to obtain an online free copy of the HECAT from the CDC website at www.cdc.gov. The next step for the proper use of the tool was to read it thoroughly. After becoming familiar with the instructions and intentions of the HECAT, a copy of health education curriculum was collected from the Ministry of education website at ttkb.meb.gov.tr. The objectives were translated into English and used for content analysis.

As an instrument, the HECAT guidance, was used and the content of the HEC was examined. HECAT is a compact analysis tool which is developed by CDC. Chapter six of HECAT was used as a frame in this study to perform the comparison. Objectives are called "knowledge \& skill expectations" which are related to healthy behavior outcomes (HBO) in HECAT. All of expectations are listed by grades: pre-K-2; 3-5; 6-8 and 9-12. These are numbered respectively for the convenience of documentation and discussion. Before each expectation, the number represents the topic abbreviation, NHES standard number, grade group (last grade in the group), and expectation item number. For instance, PA1.2.8 represents Physical Activity (PA) module, standard 1, grade group Pre-K-2, expectation item 8. In the end of the expectation HBO codes are related to healthy behavior outcomes of the related topic. HEC objectives were coded accordingly to HEC units. For instance, for the topic Healthy Life in the curriculum, "HL", number of the objective under the topic "number"; topic and number of objective "HL1" is used.

The first aim was to analyze HEC according to HECAT criteria; however, scoring of assessing did not fit into HEC. For this reason, HECAT module assessing criteria adjusted, formed, adapted and used as a comparison tool for this study. The comparative analysis was started with determination of correspondence rate of HEC units to HECAT modules. Essentially, the first nine modules were analyzed by their action verbs in respect to Revised Bloom's Taxonomy (RBT) cognitive domains (Anderson et al., 2001). The second step involved the elimination of the matching HEC objectives and HECAT expectations (knowledge and skill) according to the key words of related module. Third step was to take into consideration whether HEC objectives are overlapping with HECAT expectations or not. HECAT scoring was revised and appraisal strength criteria out of 10 for objectives comparison was created and shown in Table 2. 
Table 2. Appraisal strength criteria for objective comparison

\begin{tabular}{|c|c|c|}
\hline Criterion & Strength & Explanation \\
\hline \multirow[t]{2}{*}{ High incidence of overlapping } & 10 & All words/concepts including action verbs are overlapping. \\
\hline & 9 & $\begin{array}{l}\text { Most of words/concepts including action verbs are } \\
\text { overlapping. }\end{array}$ \\
\hline \multirow[t]{4}{*}{$\begin{array}{l}\text { Middle incidence of } \\
\text { overlapping }\end{array}$} & 8 & $\begin{array}{l}\text { All words/concepts are overlapping and action verbs are in } \\
\text { the same domain. }\end{array}$ \\
\hline & 7 & $\begin{array}{l}\text { Some of words/concepts are overlapping and action verbs } \\
\text { overlapping. }\end{array}$ \\
\hline & 7 & $\begin{array}{l}\text { Most of words/concepts are overlapping and action verbs } \\
\text { are in the same domain. }\end{array}$ \\
\hline & 7 & $\begin{array}{l}\text { All words/concepts are overlapping, but action verbs are } \\
\text { from different domain. }\end{array}$ \\
\hline \multirow[t]{3}{*}{ Low incidence of overlapping } & 6 & $\begin{array}{l}\text { Most of words/concepts are overlapping, but action verbs } \\
\text { are from different domain. }\end{array}$ \\
\hline & 5 & $\begin{array}{l}\text { Some of words/concepts are overlapping and action verbs } \\
\text { are in the same domain. }\end{array}$ \\
\hline & 4 & $\begin{array}{l}\text { Some of words/concepts are overlapping, but action verbs } \\
\text { are from different domain. }\end{array}$ \\
\hline \multirow[t]{2}{*}{$\begin{array}{l}\text { High incidence of inferential } \\
\text { overlapping }\end{array}$} & 7 & $\begin{array}{l}\text { All of words/concepts are inferential overlapping and action } \\
\text { verbs overlapping. }\end{array}$ \\
\hline & 6 & $\begin{array}{l}\text { Most of words/concepts are inferential overlapping and } \\
\text { action verbs are overlapping. }\end{array}$ \\
\hline \multirow[t]{4}{*}{$\begin{array}{l}\text { Middle incidence of } \\
\text { inferential overlapping }\end{array}$} & 5 & $\begin{array}{l}\text { All of words/concepts are inferential overlapping and action } \\
\text { verbs are in the same domain. }\end{array}$ \\
\hline & 4 & $\begin{array}{l}\text { Some of words/concepts are inferential overlapping and } \\
\text { action verbs are overlapping. }\end{array}$ \\
\hline & 4 & $\begin{array}{l}\text { Most of words/concepts are inferential overlapping and } \\
\text { action verbs are in the same domain. }\end{array}$ \\
\hline & 4 & $\begin{array}{l}\text { All of words/concepts are inferential overlapping but action } \\
\text { verbs are from the different domain. }\end{array}$ \\
\hline \multirow[t]{3}{*}{$\begin{array}{l}\text { Low incidence of inferential } \\
\text { overlapping }\end{array}$} & 3 & $\begin{array}{l}\text { Most of words/concepts are inferential overlapping but } \\
\text { action verbs are from the different domain. }\end{array}$ \\
\hline & 2 & $\begin{array}{l}\text { Some of words/concepts are inferential overlapping and } \\
\text { action verbs are in the same domain. }\end{array}$ \\
\hline & 1 & $\begin{array}{l}\text { Some of words/concepts are inferential overlapping but } \\
\text { action verbs are from the different domain. }\end{array}$ \\
\hline Not-related at all & 0 & There is no relation between sentences. \\
\hline
\end{tabular}

There is additional information for this scoring. If concepts were synonymous, the evaluation should be considered "All" criterion. Scores summed up and the average was calculated, the result determined the score of the overlapping. Zero scores are ignored and are not included in the evaluation. If more than one HEC's objectives overlap with one HECAT expectation, mean was calculated. The relative correspondence score was calculated by the formulas in Figure 1 for all grades and Figure 2 for grades 9-12:

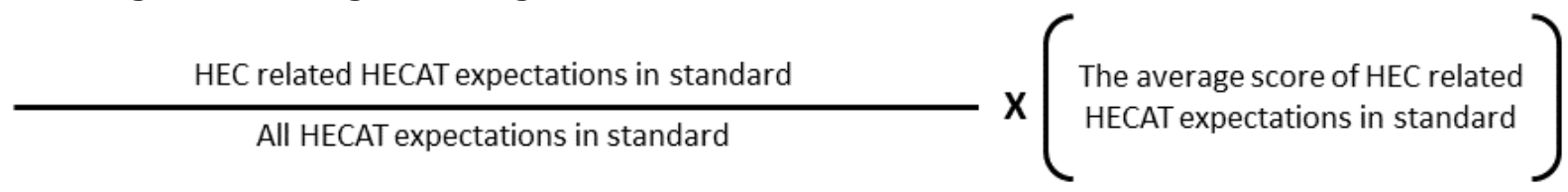

Figure 1. The relative correspondence score for all grades 


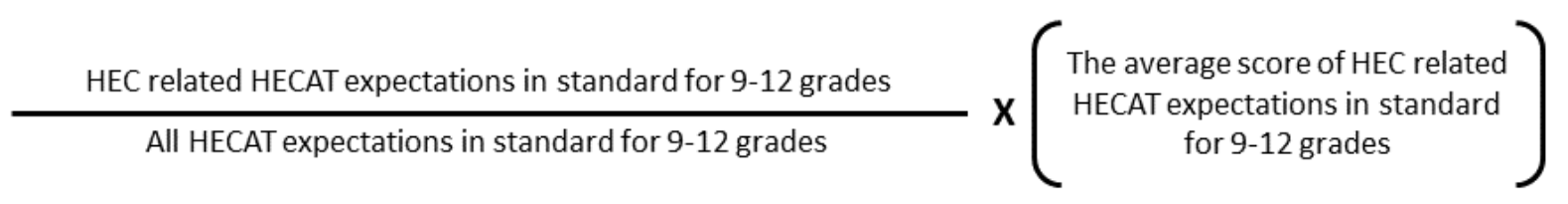

Figure 2. The relative correspondence score for grades 9-12

Finally, the result of the relative correspondence score was multiplied by 10 to calculate percentage of overlapping.

\section{Reliability and Validity}

According to Neuendorf (2002) reliability and validity are principal to the truthfulness and strength of research in content analysis. Validity is checked by comparing expected and acquired results while reliability is ensured by comparing the results of two independent coders (a researcher and an academician in this research). In order to ensure valid and reliable classification, a code book was created for the study (only for HEC) and more than one coder, whereas codes were already given in each module of HECAT. Fraenkel and Wallen (2009) define the term validity, in research to indicate the usefulness, meaningfulness and correctness of any instrument used by a researcher to access and interpret. Neuendorf (2002) states that validity aims to answer "Are we really measuring what we want to measure?" (p.12). The term reliability has been defined by Fraenkel and Wallen (2009) as "The consistency of scores or answers provided by an instrument" (p.154). A coding tool is reliable if it produces consistent results at different times, even when used by different researchers (Krippendorff, 1986). To measure reliability, first, $20 \%$ of the sampled topics from curriculum were selected randomly, and along with the instrument, given to another academician. They used the instrument to compare the selected topics. Their results were compared with the researcher's findings and then both parties come to the conclusion after several discussions.

\section{RESULTS}

The results of this research were explored through comparative content analysis. There are 10 modules on HECAT to assess an existing curriculum. The first nine modules are Alcohol and Other Drugs (AOD), Healthy Eating (HE), Mental and Emotional Health (MEH), Physical Activity (PA), Safety (S), Sexual Health (SH), Tobacco (T), Violence (V). There is an additional module called as Comprehensive Health Education (CHE) which aims to review all previous nine modules in HECAT. All modules were designed in regard to eight NHES.

HECAT and HEC were compared according to the modules and unit numbers, content list and cognitive loads, and findings are presented below. All HECAT modules have their own health behavior outcomes (HBO) which are integrated to the expectations regarding to NHES (JCNHES, 2007). Alcohol and Other Drugs (AOD), eight; Healthy Eating (HE), 13; Mental and Emotional Health (MEH), eight; Personal Health and Wellness (PHW), 12; Physical Activity (PA), seven; Safety (S), eight; Sexual Health (SH), eight; Tobacco (T), five and Violence Prevention (V) has 10 HBOs. On the contrary, HEC has only objectives. HEC has seven units, while HECAT has nine modules. The study focused on objectives, key words and expectations. The results of comparison of HEC and HECAT contents were given in Table 3. 
Table 3. HECAT vs. HEC: Related modules and units

\begin{tabular}{|c|c|c|c|}
\hline Code & HECAT Module & Code & HEC Unit \\
\hline \multirow[t]{5}{*}{ AOD } & Alcohol and Other Drugs & HL & Healthy Life \\
\hline & & MEH & Mental and Emotional Health \\
\hline & & $\mathrm{HHH}$ & Harmful Habits for Health \\
\hline & & FL\&MIH & Family Life and Maternal - Infant Health \\
\hline & & FCPAD & Fundamental Concepts and Principles About Diseases \\
\hline \multirow[t]{5}{*}{$\mathrm{HE}$} & Healthy Eating & HL & Healthy Life \\
\hline & & GD & Growth and Development \\
\hline & & IPH & Improvement and Prevention of Health \\
\hline & & MEH & Mental and Emotional Health \\
\hline & & FCPAD & Fundamental Concepts and Principles About Diseases \\
\hline \multirow[t]{3}{*}{ MEH } & Mental and Emotional Health & HL & Healthy Life \\
\hline & & GD & Growth and Development \\
\hline & & MEH & Mental and Emotional Health \\
\hline \multirow[t]{5}{*}{ PHW } & Personal Health and Wellness & $\mathrm{HL}$ & Healthy Life \\
\hline & & GD & Growth and Development \\
\hline & & IPH & Improvement and Prevention of Health \\
\hline & & MEH & Mental and Emotional Health \\
\hline & & FCPAD & Fundamental Concepts and Principles About Diseases \\
\hline \multirow[t]{4}{*}{ PA } & Physical Activity & HL & Healthy Life \\
\hline & & IPH & Improvement and Prevention of Health \\
\hline & & MEH & Mental and Emotional Health \\
\hline & & FCPAD & Fundamental Concepts and Principles About Diseases \\
\hline \multirow[t]{2}{*}{ S } & Safety & HL & Healthy Life \\
\hline & & MEH & Mental and Emotional Health \\
\hline \multirow[t]{5}{*}{ SH } & Sexual Health & $\mathrm{HL}$ & Healthy Life \\
\hline & & GD & Growth and Development \\
\hline & & IPH & Improvement and Prevention of Health \\
\hline & & MEH & Mental and Emotional Health \\
\hline & & FCPAD & Fundamental Concepts and Principles About Diseases \\
\hline $\mathrm{T}$ & Tobacco & $\mathrm{HHH}$ & Harmful Habits for Health \\
\hline \multirow[t]{2}{*}{$\mathrm{V}$} & Violence Prevention & $\mathrm{HL}$ & Healthy Life \\
\hline & & MEH & Mental and Emotional Health \\
\hline
\end{tabular}

Exploration of action verbs and their classification based on Revised Bloom's Taxonomy (RBT) was conducted and the content by cognitive domains of HEC related action verbs are listed in Figure 3. 


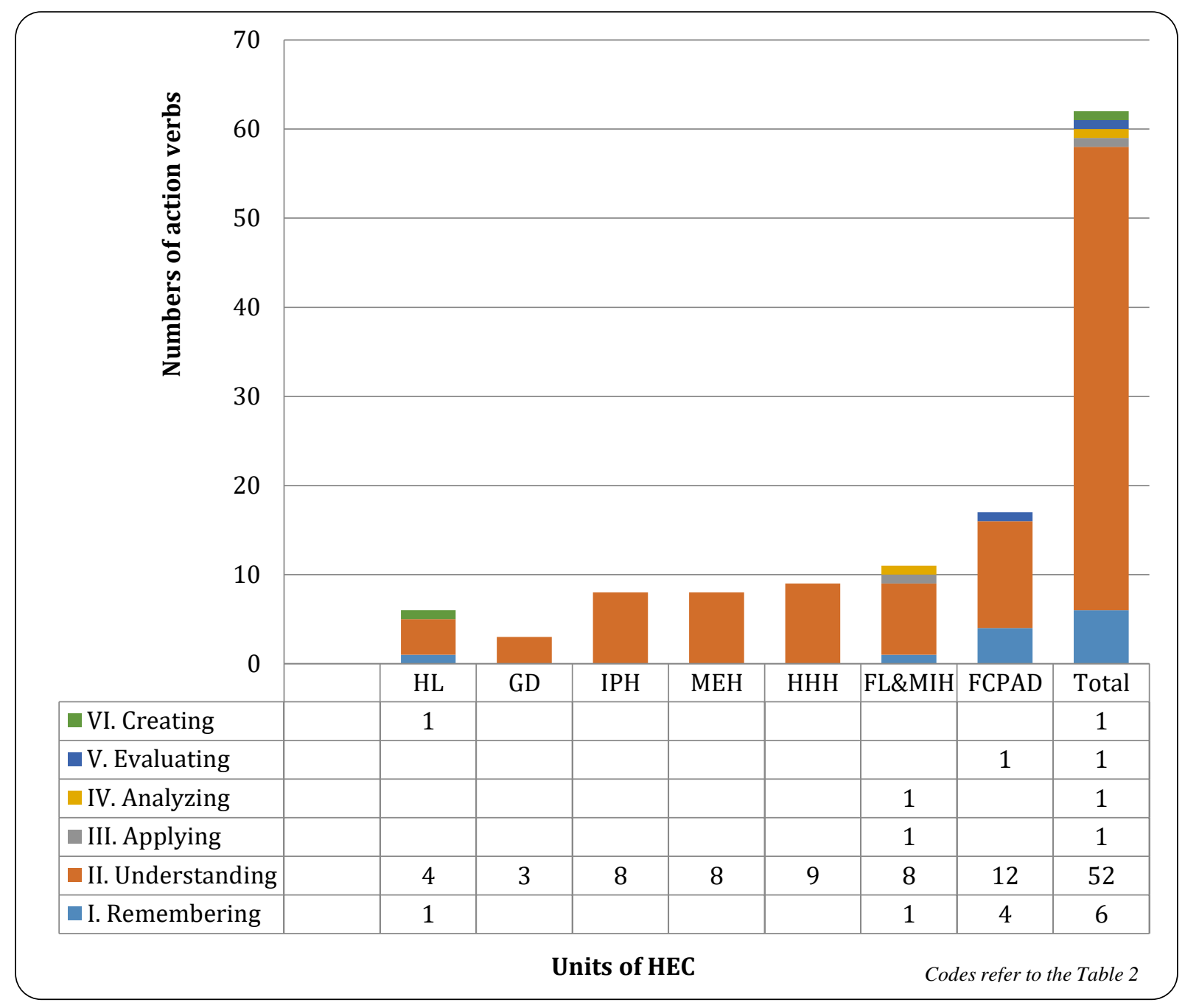

Figure 3. HEC's RBT related action verbs

HEC has 62 action verbs in total and 52 of them belong to understanding the level of RBT with the action verb "explain". Most of the objectives, 17 of them, located in Fundamental concepts and principles on diseases (FCPAD) unit; HECAT modules related HEC's objectives were found 45 which are delivered throughout the modules. Incompatible HEC objectives were calculated 17. HECAT's RBT cognitive domains related action verbs' numbers are shown in Table 4. 
Table 4. RBT related action verbs of HECAT

\begin{tabular}{|c|c|c|c|c|c|c|c|c|c|c|c|}
\hline Domains & Verbs & AOD & HE & MEH & PHW & PA & $\mathbf{S}$ & SH & $\mathbf{T}$ & $\mathbf{V}$ & Total \\
\hline \multirow{8}{*}{$\begin{array}{l}\text { I. Remembering } \\
\text { Total: } 81\end{array}$} & choose & 3 & 3 & 3 & 3 & 3 & 3 & 2 & 3 & 3 & 26 \\
\hline & define & 0 & 0 & 0 & 0 & 0 & 0 & 0 & 0 & 1 & 1 \\
\hline & give information & 1 & 1 & 1 & 1 & 1 & 1 & 0 & 1 & 1 & 8 \\
\hline & list & 0 & 0 & 1 & 1 & 0 & 4 & 1 & 0 & 0 & 7 \\
\hline & locate & 1 & 2 & 2 & 2 & 2 & 2 & 2 & 2 & 1 & 16 \\
\hline & name & 0 & 1 & 0 & 0 & 0 & 0 & 0 & 0 & 0 & 1 \\
\hline & recognize & 0 & 0 & 0 & 0 & 0 & 0 & 0 & 0 & 2 & 2 \\
\hline & state & 2 & 2 & 2 & 4 & 2 & 3 & 1 & 2 & 2 & 20 \\
\hline \multirow{6}{*}{$\begin{array}{l}\text { II. Understanding } \\
\text { Total: } 840\end{array}$} & classify & 0 & 1 & 0 & 0 & 0 & 0 & 0 & 0 & 0 & 1 \\
\hline & demonstrate & 27 & 20 & 31 & 26 & 22 & 28 & 21 & 18 & 29 & 222 \\
\hline & describe & 24 & 35 & 41 & 32 & 30 & 34 & 28 & 19 & 40 & 283 \\
\hline & explain & 21 & 26 & 37 & 23 & 21 & 22 & 32 & 15 & 40 & 237 \\
\hline & give example & 0 & 0 & 1 & 0 & 0 & 0 & 0 & 0 & 0 & 1 \\
\hline & summarize & 7 & 10 & 10 & 13 & 8 & 8 & 24 & 9 & 7 & 96 \\
\hline \multirow{5}{*}{$\begin{array}{l}\text { III. Applying } \\
\text { Total: } 297\end{array}$} & apply & 2 & 1 & 1 & 1 & 1 & 1 & 1 & 1 & 1 & 10 \\
\hline & identify & 17 & 31 & 30 & 30 & 24 & 36 & 10 & 15 & 26 & 219 \\
\hline & implement & 1 & 1 & 1 & 1 & 1 & 1 & 1 & 1 & 1 & 9 \\
\hline & track & 1 & 1 & 1 & 1 & 1 & 1 & 0 & 0 & 1 & 7 \\
\hline & use & 5 & 6 & 6 & 6 & 6 & 6 & 6 & 6 & 5 & 52 \\
\hline \multirow{5}{*}{$\begin{array}{l}\text { IV. Analyzing } \\
\text { Total: } 306\end{array}$} & analyze & 26 & 22 & 29 & 22 & 21 & 23 & 29 & 24 & 32 & 228 \\
\hline & differentiate & 4 & 2 & 3 & 1 & 3 & 1 & 2 & 1 & 1 & 18 \\
\hline & distinguish & 3 & 3 & 2 & 2 & 2 & 2 & 2 & 3 & 3 & 22 \\
\hline & examine & 2 & 1 & 2 & 1 & 1 & 1 & 1 & 2 & 1 & 12 \\
\hline & set & 4 & 3 & 3 & 3 & 3 & 3 & 2 & 2 & 3 & 26 \\
\hline \multirow{7}{*}{$\begin{array}{l}\text { V. Evaluating } \\
\text { Total: } 204\end{array}$} & assess & 5 & 4 & 4 & 4 & 4 & 4 & 4 & 4 & 4 & 37 \\
\hline & decide & 1 & 1 & 1 & 1 & 1 & 1 & 0 & 1 & 1 & 8 \\
\hline & determine & 9 & 5 & 7 & 6 & 7 & 7 & 7 & 6 & 5 & 59 \\
\hline & evaluate & 7 & 5 & 7 & 5 & 6 & 5 & 7 & 7 & 5 & 54 \\
\hline & justify & 1 & 1 & 2 & 2 & 1 & 1 & 2 & 1 & 1 & 12 \\
\hline & persuade & 7 & 3 & 3 & 3 & 3 & 3 & 5 & 3 & 3 & 33 \\
\hline & prioritize & 0 & 0 & 0 & 0 & 0 & 1 & 0 & 0 & 0 & 1 \\
\hline \multirow{8}{*}{$\begin{array}{l}\text { VI. Creating } \\
\text { Total: } 74\end{array}$} & adapt & 1 & 1 & 1 & 1 & 1 & 1 & 1 & 1 & 1 & 9 \\
\hline & collaborate & 2 & 2 & 2 & 2 & 2 & 2 & 3 & 2 & 2 & 19 \\
\hline & develop & 1 & 1 & 1 & 1 & 1 & 1 & 1 & 1 & 1 & 9 \\
\hline & discuss & 0 & 0 & 1 & 0 & 0 & 0 & 0 & 0 & 0 & 1 \\
\hline & formulate & 1 & 1 & 1 & 1 & 1 & 1 & 1 & 1 & 1 & 9 \\
\hline & generate & 1 & 1 & 1 & 1 & 1 & 1 & 1 & 1 & 1 & 9 \\
\hline & predict & 2 & 2 & 2 & 2 & 2 & 2 & 2 & 2 & 2 & 18 \\
\hline & TOTAL & 189 & 199 & 240 & 201 & 182 & 211 & 199 & 154 & 227 & 1802 \\
\hline
\end{tabular}

Expectations of HECAT all have variety of 43 verbs in total and 38 of them are action verbs related to RBT cognitive domains. In addition to this, four of them belong to affective domain (encourage, make a commitment, make request and take), and one was remained as uncategorized (access). In total, 1869 verbs are used in HECAT and 1802 of them action verbs. Most commonly used verbs are 'describe' 283 times (understanding), 'explain' 237 times (understanding) and 'analyze' 228 times (analyzing). Define, name, classify, give example, prioritize and discuss have been used only one time. As a result, the most represented level was understanding, whereas applying was the least represented level in both curricula. 
In the comparison of two curricula HEC and HECAT, HEC represents 62 objectives only for grade 9 while HECAT has 641 for $9-12$ out of 1869 for K-12 grades. HECAT has variety of topics which overlap in some points of HEC. According to RBT, HEC frequently remains at the level of understanding whereas HECAT covers all of the levels mainly at understanding level. The result of analysis, HEC objectives correspondence to HECAT module's standards' expectations, averages of appraisal strength scores, the relative correspondence scores and correspondence rate are listed for all grades in Table 5, for 9-12 grades in Table 6. All the averages were given in Figure 4.

Table 5. The appraisal strength table of all modules - all grades

\begin{tabular}{|c|c|c|c|c|c|}
\hline Module \& Standard & Grades & Total Exp.* & Related Exp.* & Total Score & $\%$ \\
\hline AOD S1 & All & 50 & 22 & 2.62 & 26 \\
\hline HE S1 & All & 67 & 16 & 1.13 & 11 \\
\hline MEH S1 & All & 93 & 21 & 1.08 & 11 \\
\hline PHW S1 & All & 60 & 40 & 3.10 & 31 \\
\hline PA S1 & All & 45 & 9 & 1.24 & 12 \\
\hline SH S1 & All & 97 & 65 & 3.73 & 37 \\
\hline T S1 & All & 40 & 28 & 3.48 & 35 \\
\hline V S1 & All & 89 & 9 & .46 & 5 \\
\hline AOD S2 & All & 28 & 2 & .18 & 2 \\
\hline HE S2 & All & 31 & 2 & .42 & 4 \\
\hline MEH S2 & All & 31 & 2 & .45 & 5 \\
\hline PHW S2 & All & 31 & 2 & .61 & 6 \\
\hline PA S2 & All & 31 & 2 & .55 & 5 \\
\hline S S2 & All & 31 & 2 & .39 & 4 \\
\hline SH S2 & All & 21 & 2 & .86 & 9 \\
\hline V S2 & All & 31 & 1 & 19 & 2 \\
\hline AOD S3 & All & 24 & 1 & .21 & 2 \\
\hline MEH S3 & All & 27 & 8 & .52 & 5 \\
\hline AOD S4 & All & 20 & 3 & .75 & 8 \\
\hline HE S4 & All & 13 & 1 & .38 & 4 \\
\hline MEH S4 & All & 24 & 3 & .71 & 7 \\
\hline PHW S4 & All & 19 & 1 & .47 & 5 \\
\hline PA S4 & All & 15 & 1 & .60 & 6 \\
\hline S S4 & All & 19 & 1 & .11 & 1 \\
\hline SH S4 & All & 18 & 2 & .67 & 7 \\
\hline V S4 & All & 22 & 2 & .73 & 7 \\
\hline MEH S5 & All & 26 & 7 & .73 & 7 \\
\hline PA S7 & All & 14 & 3 & .79 & 8 \\
\hline MEH S8 & All & 15 & 1 & .07 & 1 \\
\hline
\end{tabular}

For all grades, maximum overlap was found at Sexual Health (SH) module S1 (37\%). Second was Tobacco (T) S1 (35\%). Third one was Personal Health and Wellness (PHW) S1(31\%). Minimum overlap was found at Safety (S) S4 and Mental and Emotional Health (MEH) S8 modules (1\%). The average score for overlapping ones is nearly nine percent (9\%). 
Table 6. Appraisal strength table of all modules - 9-12 grades

\begin{tabular}{ccrrrr}
\hline Module \& Standard & Grades & Total Exp. $^{*}$ & Related Exp. & Total Score & $\mathbf{\%}$ \\
\hline AOD S1 & $9-12$ & 22 & 7 & 2.00 & 20 \\
HE S1 & $\mathbf{9 - 1 2}$ & $\mathbf{2 0}$ & $\mathbf{1 0}$ & $\mathbf{2 . 9 0}$ & $\mathbf{2 9}$ \\
MEH S1 & $9-12$ & 26 & 6 & 1.10 & 11 \\
PHW S1 & $\mathbf{9 - 1 2}$ & $\mathbf{1 3}$ & $\mathbf{8}$ & $\mathbf{2 . 7 4}$ & $\mathbf{2 7}$ \\
PA S1 & $9-12$ & 14 & 1 & .43 & 4 \\
SH S1 & $9-12$ & 43 & 11 & 1.09 & 11 \\
T S1 & $9-12$ & 13 & 7 & 2.46 & 25 \\
V S1 & $9-12$ & 30 & 4 & .67 & 7 \\
MEH S3 & $9-12$ & 9 & 4 & .44 & 4 \\
AOD S4 & $9-12$ & 6 & 3 & 2.50 & 25 \\
HE S4 & $9-12$ & 4 & 1 & 1.25 & 13 \\
MEH S4 & $9-12$ & 6 & 1 & .83 & 8 \\
PHW S4 & $9-12$ & 4 & 1 & 2.25 & 23 \\
PA S4 & $9-12$ & 4 & 1 & 2.25 & 23 \\
S S4 & $9-12$ & 5 & 1 & .40 & 4 \\
SH S4 & $9-12$ & 6 & 2 & 2.00 & 20 \\
V S4 & $\mathbf{9 - 1 2}$ & $\mathbf{5}$ & $\mathbf{2}$ & $\mathbf{3 . 2 0}$ & $\mathbf{3 2}$ \\
MEH S5 & $9-12$ & 8 & 2 & .25 & 3 \\
MEH S8 & $9-12$ & 6 & *Expectation (aka; objective)
\end{tabular}

For grades 9-12, maximum overlap was found at Violence (V) module's S1 (32\%). Second was Healthy Eating (HE) S1 (29\%). Third one was Personal Health and Wellness S1 (27\%). Minimum overlap was found at Emotional Health (MEH) S8 module (2\%). The average score for overlapping ones is fifteen percent (15\%).

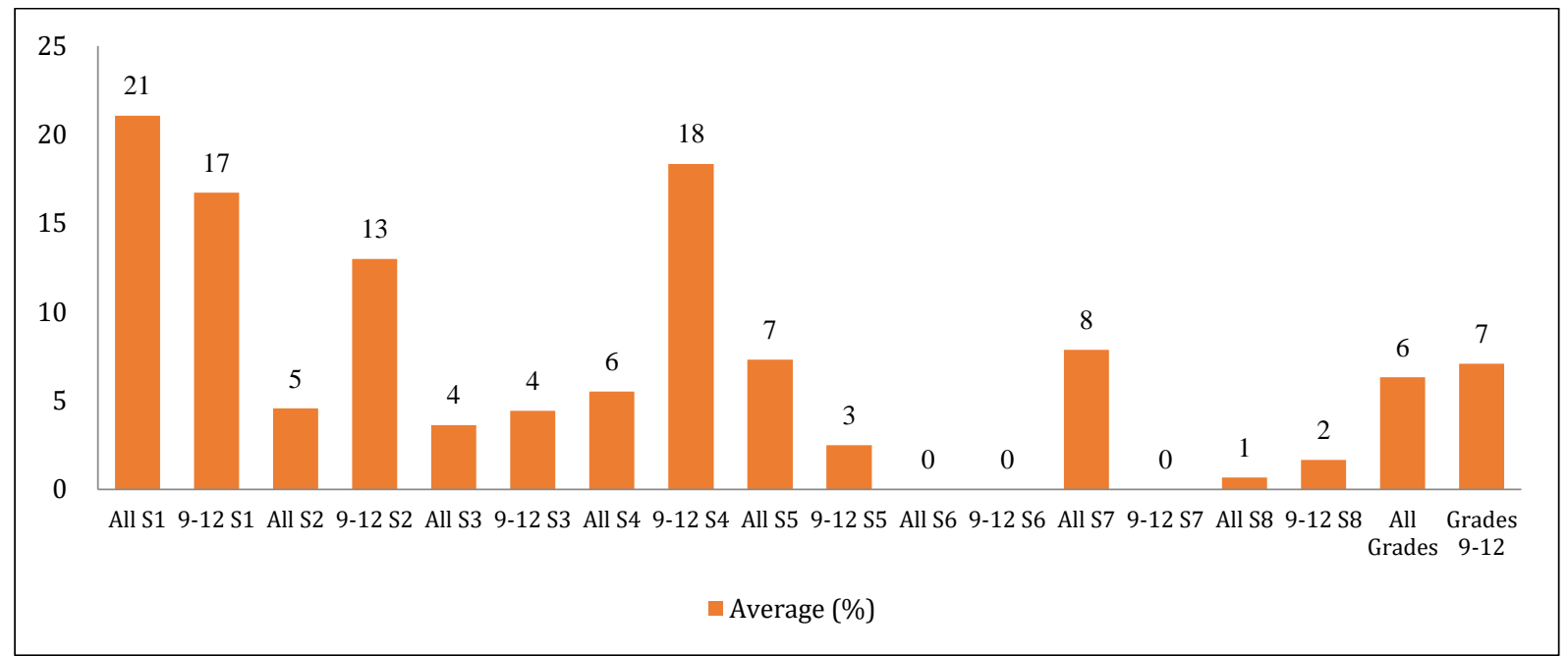

Figure 4. Appraisal strength of all standards \& grades

Overall, averages for all standards \& grades, maximum overlap was found at Standard 1 for all grades (21\%). Second was Standard 1 for grades 9-12 (17\%). Third one was Standard 4 for grades 9-12 (18\%). Standard 6 for all and 9-12 grades, Standard 7 for grades 9-12 did not overlap with any objectives of HEC. The average score for overlapping ones is six percent $(6 \%)$ for all grades and seven percent (7\%) for grades 9-12.

\section{DISCUSSION and CONCLUSIONS}

Health education is a crucial part of K-12 education which provides young people information and skills they need to be healthy and successful when they arrive adulthood. Above all, health education should be integrated to the school culture primarily. The major findings that have been obtained through the research process are: 
- HEC is a compact curriculum which draws a framework in education of health. It helps to reduce the workload of the teacher to teach and assess. Limited objectives and lower Revised Bloom Taxonomy cognitive load simplify every student to reach every student in the classroom.

- HEC also challenges teachers to differentiate the curriculum content, and the assessment required to meet individual or community needs.

- There is a lack of structured and well-organized module system in HEC.

- Duration and poor organization of entire course limits the health education by HEC.

- HEC does not have any assessment criteria or rubric.

In addition to what is mentioned above, another critical finding of the study is that the current curriculum is mainly conceptual. The strongest point of HEC was concerning on conceptual knowledge. These concepts are included under the topics: Sexual Health, Tobacco and Personal Health and Wellness. Although this coverage of concepts is important, HEC is not effective on developing behavior, and not adequate on health education related concepts as well (strength of conceptual awareness: $17 \%$ whereas, strength of behavioral awareness: $8 \%$ in HEC compared to HECAT). To be improved, the current curriculum needs to identify skills, behaviors, and actions for students can take to ensure they stay healthy. Thus, they can also learn how to support the health of their families and their communities.

In this research, findings showed that the health education cannot be succeeded with the HEC which is delivered only at grade 9 compared to HECAT in the United States. The relationship between healthy behaviors and education is examined by some researchers in Turkey (Mocan \& Altindag, 2014; Tansel \& Karaoglan, 2014). Mocan and Altindag (2014) highlighted the importance of schooling and stated that education is a good indicator for being healthy. Similarly, Tansel and Karaoglan (2014) found that education has the strongest effect on all healthy behaviors. In this regard, concepts are not sufficient to be healthy if behavior does not develop accordingly. Developing behaviors was not the main concern of HEC ( $M=4 \%$ for all grades; $M=$ $8 \%$ for grades 9-12) which does not help to be healthy for generations.

The competency of HEC was not sufficient to build that kind of behaviors according to this study (the strength of HEC for grade 9 was calculated $7.09 \%$ compared to HECAT). Kann, Telljohann and Wooley (2007) stated that health education has the latent competency to promote students to sustain and develop their wellness and increase control over and avoid health-risky behaviors. Avoidance and controlling health-risky behaviors by students can be improved only with a well-designed curriculum.

This study can be set down as the first step which will contribute to develop effective Turkish national health education standards (TNHES, table 7) for K-12. These outlined standards can help to promote health across the country and put the health education into a certain framework. The results would contribute to induce teachers' attitudes positively into the health education courses. In the long term, health status of new generation might be enhanced by recommendations of this research. In addition, everyone would agree that health is the main priority for human-kind and this research suggests a framework for improving the quality of lifespan in terms of health concerns in Turkey.

Table 7. Recommended TNHES

\begin{tabular}{lll}
\hline Standard & Content & Key Concept \\
\hline 1 & Students will recognize health related concepts. & $\begin{array}{l}\text { Knowledge } \\
\text { (Conceptual) } \\
2\end{array}$ \\
$\begin{array}{l}\text { Students will demonstrate the ability to access valid } \\
\text { information such as laws and rights on health. } \\
\text { Students will realize themselves and their surroundings. } \\
\text { (Conceptual \& behavioral) } \\
\text { Self-awareness } \\
\text { (Conceptual \& behavioral) }\end{array}$ & $\begin{array}{l}\text { Students will apply any facility to be free of disease or } \\
\text { infirmity and practice healthy behaviors in their daily life. } \\
\text { Students will advocate healthy behaviors for everyone } \\
\text { around them and in the community. }\end{array}$ & $\begin{array}{l}\text { Advocacy } \\
\text { (Behavioral) }\end{array}$ \\
\hline
\end{tabular}


In this research, one of the aim was to identify strengths and limitations in health education and the other one was to provide guidelines for improvement of the curriculum. The study showed that health education in Turkey should be more comprehensive, rather than including health topics in only grade 9 , students of all grades need to learn about healthy living. From the global perspective, developing a competitive health education curriculum should rely on scientific theories. Another issue; provision of framework for a qualified health education curriculum; became requisite in the $21^{\text {st }}$ century needs.

\section{REFERENCES}

Anderson, L. W., Krathwohl, D. R., Airasian, P. W., Cruikshank, K. A., Mayer, R. E., Pintrich, P. R., ... \& Wittrock, M. C. (2001). A taxonomy for learning, teaching, and assessing: A revision of Bloom's taxonomy of educational objectives. White Plains, NY: Longman.

CDC (2012). HECAT: Health education curriculum analysis tool, 2012. Atlanta, GA: Centers for Disease Control and Prevention.

CDC (2015, June 17). National health education standards. Centers for Disease Control and Prevention. Retrieved from http://www.cdc.gov/healthyschools/sher/standards/index.htm

Cerrah, L., \& Ayas, A. (2003). Meslek liselerinde görev yapan biyoloji öğretmenlerinin karşılaştıkları problemler: biyoloji ve sağlık bilgisi öğretim programına bir bakış [The problems that vocational schools' biology teachers come cross: a look the biology and human healthy course]. Milli eğitim dergisi, 159, 149-159.

Eriksson, M., \& Lindström, B. (2008). A salutogenic interpretation of the Ottawa Charter. Health promotion international, 23(2), 190-199.

Falkenburry, K. L. (2011). A content analysis of the health education curriculum at a rural southern Illinois high school using the health education curriculum analysis tool (HECAT) (Unpublished master thesis). Southern Illinois University, Carbondale.

Fraenkel, J.R. \& Wallen, N.E. (2009). How to design and evaluate research in education (7th ed.). New York, NY: Mc Graw Hill.

JCNHES (2007). National health education standards: Achieving excellence. Atlanta, Georgia: Joint Committee on National Health Education Standards, American Cancer Society.

Kann, L., Telljohann, S. K., \& Wooley, S. F. (2007). Health education: Results from the school health policies and programs study 2006. Journal of school health, 77(8), 408-434.

Krippendorff, K. (1986). Content analysis: An introduction to its methodology. California: Sage Publications.

Menzawa, K. (2014). Comparison of school health education in America and Japan: An examination of U.S. national health education standards (NHES), health education curriculum analysis tool (HECAT, 2012, and Health Smart for early elementary grades [Abstract]. Bulletin of the Faculty of Education, Hirosaki University, 111, 129-136.

Minbuta, M. Anzai, H. Naka, A. Yasuda, E. \& Menzawa, K. (2012). A Study on developing health education curricula and teaching material for first and second grades in elementary school: An examination of a potential program and teaching materials [Abstract]. Bulletin of the Faculty of Education, Hirosaki University, 107, 101-111.

MoNE (n.d). Geçmişten günümüze kurul kararları [Resolutions of board from past to present]. Ministry of National Education. Retrieved July 4,2016 from http://ttkb.meb.gov.tr/www/gecmisten-gunumuzekurul-kararlari/icerik/152

MoNE (2012). Ortaöğretim sağlık bilgisi dersi öğretim programı [Secondary health education course curriculum]. Ankara, Millı̂ Eğitim Bakanlığı, Mesleki ve Teknik Eğitim Genel Müdürlüğü. Ministry of National Education.

Mocan, N., \& Altindag, D.T. (2014). Education, cognition, health knowledge, and health behavior. The European journal of health economics, 15(3), 265-279.

Neuendorf, K. A. (2002). The content analysis guidebook. Thousand Oaks, CA: Sage Publications.

Sağlam, N. (1996). Orta öğretimde sağllk bilgisi dersinin niteliği ve öğrencilerin derse ilgileri [The quality of and students' interest to health education in the secondary education] Hacettepe üniversitesi eğitim fakültesi dergisi, 12(12), 201-206.

Saracci, R. (1997). The World Health Organization needs to reconsider its definition of health. British medical journal, 314(7091), 1409-1410.

Tansel, A. \& Karaoglan, D. (2014, June 20). Health behaviors and education in Turkey. Retrieved from: http://dx.doi.org/10.2139/ssrn.2457105 
TURKSTAT (2014). 2014 Türkiye sağlık araştırması [Turkish health research]. Türkiye istatistik kurumu haber bülteni, 18854, Ankara. Turkish Statistics Institute.

TURKSTAT (2017). 2016 Türkiye ölüm nedeni istatistikleri [Turkish cause of death statistics]. Türkiye istatistik kurumu haber bülteni, 24572, Ankara. Turkish Statistics Institute.

Weber, R. P. (1985). Basic content analysis. Beverly Hills: SAGE Publications.

WHO (1948). Official records of the World Health Organization (No. 2). United Nations, World Health Organization, Interim Commission.

WHO (1986). Health and Welfare Canada, Canadian Public Health Association. Ottawa charter for health promotion, 425-30. World Health Organization

WHO (2012). Health education: Theoretical concepts, effective strategies and core competencies. World Health Organization. Regional Office for the Eastern Mediterranean.

WHO (2016). The global guardian of public health [Brochure]. N.P.: World Health Organization. 